REVIEW ARTICLE

PRACA POGLĄDOWA

\title{
PERINATAL AND INFANT MORTALITY IN THE TRANSCARPATHIAN REGION AND UKRAINE AGAINST THE BACKGROUND OF THE EUROPEAN UNION AND THE WORLD: A COMPARATIVE ANALYSIS AND POSSIBLE PROBLEMS
}

D0I: 10.36740/WLek202003138

\author{
Ivan M. Rogach, Gennady 0. Slabkiy, Renata Y. Pogorilyak, Angelika 0. Keretsman, Ivan I. Gadzhega \\ DEPARTMENT OF SOCIAL MEDICINE AND HYGIENE (WITH A HISTORY OF MEDICINE), FACULTY OF MEDICINE, UZHHOROD NATIONAL UNIVERSITY, \\ UZHHOROD, UKRAINE
}

\begin{abstract}
The aim of this article was to analyze the dynamics of perinatal mortality and mortality up to 1 year in the Transcarpathian region and Ukraine in comparison with other countries of Europe and the world.

Materials and methods: The study is based on data from the Transcarpathian Regional Medical Information and Analytical Center, the Center for Medical Statistics of the Ministry of Health of Ukraine, the European database «Health for All» and the Center for Research of Health Services at the University of Kent, Kiev Economic Institute of the Kiev School of Economics (July 2017).

Review: In 2016, mortality under the age of 1 year in Ukraine amounted to 7.4 per 1000 live births, which is $13.5 \%$ lower than the same indicator in 2012 (8.4). According to perinatal mortality, in Ukraine this indicator has a level of $8.59 \%$, while the average in the EU countries does not exceed $6.01 \%$.

Conclusions: Perinatal and mortality rates up to 1 year in the Transcarpathian region, as in Ukraine as a whole, are an order of magnitude higher than the European average. The same negative trend in the survival of newborns in Transcarpathia and in Ukraine.
\end{abstract}

KEY WORDS: perinatal mortality, infant mortality, regionalization, perinatal care

Wiad Lek. 2020;73(3):603-608

\section{INTRODUCTION}

The population of any country today is experiencing a difficult period in terms of conditions and lifestyle. Daily stresses, overstrain, an increase in the number of cases of self-medication through uncontrolled hyperinformatization of society, ecology, lifestyle have a direct impact on the health status of the population. In such conditions, the issue of restoring the population, preserving the life of each newborn with a parallel increase in the quality of life not only of the child population, but of the whole society becomes more and more urgent. In this format, the problem of preserving the life and health of each child has a high medical and social significance and determines the well-being and national security of the country [1].

One of the main determinants of preserving the life and health of each child is the state of health of the parents, including the mother, the pregnant woman, the physiological maturity of the fetus, the adequacy of management and the state of the course of labor. Given the importance of the infant mortality rate for civilizational development, this area of research has been and remains relevant both in Ukraine and around the world. This problem was dedicated to the work of the classics of Ukrainian demography and sanitary statistics O.V. Korchak-Chepurkovsky and Yu.O. Korchak-Chepurkovsky, M. Ptukha, S.A. Tomilin, A. P.
Khomenko [2]. To assess the state of health of the child population, and in parallel - the quality of medical care for mothers and children, remains a complex multifactorial problem. One of the key indicators that can correctly and efficiently illuminate the actual state of these issues remains mortality in the perinatal period.

Now there are a huge number of sources from which those related to perinatal mortality are of significant interest $[3,4,5,6]$, since this segment plays a decisive role in shaping the overall infant mortality rate in developed countries and is much more difficult to influence by policy in health than, say, infectious diseases [2].

In Ukraine, as well as around the world, over the past decade, thanks to the implementation of World Health Organization (WHO) strategies and programs, focused mainly on reproductive health priorities, it has been possible to significantly reduce maternal, birth and perinatal losses. This was also facilitated by the reorientation of healthcare institutions to a scientifically-based area of activity, evidence in practice, and certain aspects of the regionalization of medical care for these segments of the population.

Even taking into account the positive tendency for these indicators to change, the level of maternal and child health in our country remains one of the least acceptable in comparison with other European Union (EU) countries and the 


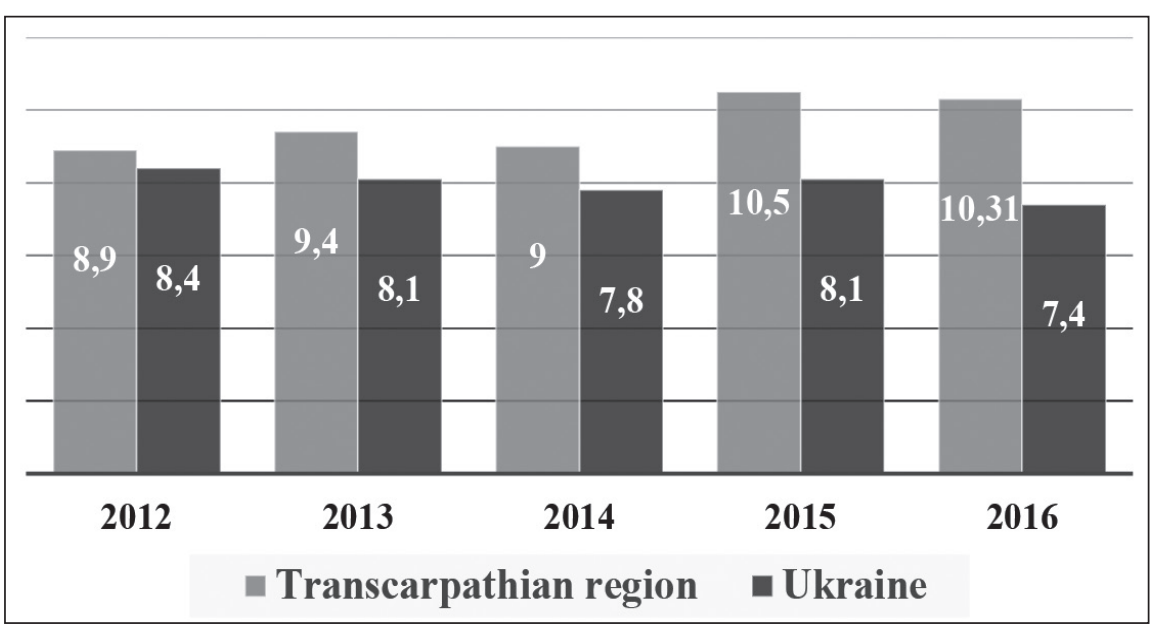

Figure. 1. Mortality rates for children under 1 year old for 2012-2016 in the Transcarpathian region and Ukraine (per 1000 live births). world as a whole. Today, in developed EU countries, the main methods for optimizing indicators of maternal health, perinatal pathology and the course of childbirth remain the use of modern information technology and scientific achievements, principles of evidence, continuity in perinatal medical practice, which is embodied in the introduction of models of regionalization of perinatal care (RPC). According to reliable studies, the organization of a three-level system of perinatal care (PC), the modernization of technical equipment in Japan, the USA and Western Europe allowed several times to reduce maternal and fetal-baby losses, the incidence and mortality rate of newborns and young children [1].

\section{THE AIM}

The aim of this article was to analyze and evaluate the dynamics of perinatal mortality and mortality rates up to 1 year in the Transcarpathian region and Ukraine as a whole compared with other countries of Europe and the world; put forward hypotheses about the possible causes of this situation.

\section{MATERIALS AND METHODS}

The study was based on data from the Transcarpathian Regional Medical Information and Analytical Center, the Center for Medical Statistics of the Ministry of Health of Ukraine, the European database "Health for All" and the Center for Health Services Studies University of Kent, Kyiv Economics Institute Kyiv School of Economics (July 2017). Statistical data processing and a graphical representation of the results were performed using standard Microsoft Office Word, Exel 2010 software services, as well as STATISTIKA, V.10.0.

\section{REVIEW}

For the period 2012-2016 Infant mortality rates in Ukraine had a positive trend. In 2016, mortality under 1 year in Ukraine amounted to 7.4 per 1000 live births, which is $13.5 \%$ lower than the same indicator in 2012 (8.4). Unlike Ukraine, the Transcarpathian region by a similar indicator has a level above the national average and is moving upward. Thus, the infant mortality rate in Transcarpathia in 2016 increased by $15.8 \%$ compared to 2012 (Figure. 1).

A similar indicator in the EU and the world had a diverse trend, but was significantly lower than in Ukraine as a whole and Transcarpathia in particular. So, as of 2016, the mortality rate of children under 1 year of age in the EU was 3.78 per 1,000 live births. In the dynamics of 2012-2016 This indicator in the EU countries decreased by $5.8 \%$. Similar indicators in other countries as of 2016 ranged from $1.4 \%$ in Iceland and Luxembourg, to 9.8 \%o in Romania and $12.9 \%$ in the Republic of Moldova, presented in Table I.

If we compare the rate of perinatal mortality in Ukraine and similar in the EU and the world, then in our country, with a positive trend, this indicator changes from $9.78 \%$ in 2012 . Up to $8.59 \%$ in $2016(-13.85 \%)$, there is still a predominance of its average perinatal mortality rate in the EU countries (6.09 in 2012 and 6.01 by 2016) - (see Table II).

According to the WHO, the level of perinatal mortality should be due to its high level among those born with low body weight (less than $1500 \mathrm{~g}$ ), which, in turn, is due to its high level among those born with very low body weight (500-999 g) [7 ]. Compared with other EU countries and the world, Ukraine maintains a relatively high level of perinatal mortality in children with low and normal body weight ( $\geq 1000 \mathrm{~g}$ ), despite the positive dynamics for the period 2012-2016. (Table III).

One of the goals of ensuring a healthy lifestyle and promoting well-being for all at any age, among the goals of sustainable development, is determined until 2030 "to put an end to mortality, which can be prevented, for newborns and children under 5 years of age", to reduce the maternal mortality rate, to ensure general access to services on sexual and reproductive health, including family planning services, information and education, and integrating reproductive health into national strategies and programs $[7,8]$.

These tasks in Ukraine, unfortunately, are not fully implemented today, in particular in certain regions. This clearly demonstrates the survival rate of newborns with low body weight (1000-1499 g) in the Transcarpathian region compared with other regions of the country (Figure. 2). 
Table. 1. Dynamics of child mortality rates up to 1 year in the EU and the world for the period 2012-2016 (per 1000 live births).

\begin{tabular}{|c|c|c|c|c|c|}
\hline Year & 2012 & 2013 & 2014 & 2015 & 2016 \\
\hline \multicolumn{6}{|l|}{ Country } \\
\hline The Netherlands & 3,5 & 3,3 & 3,2 & 3,2 & 3,15 \\
\hline Norway & 2,3 & 2,3 & 2,2 & 2,0 & 2,0 \\
\hline Poland & 4,5 & 4,5 & 4,45 & 4,3 & 4,2 \\
\hline Portugal & 3,1 & 3,1 & 3,1 & 2,9 & 2,8 \\
\hline Romania & 10,9 & 10,5 & 10,1 & 9,85 & 9,8 \\
\hline Russia & 9,1 & 8,6 & 8,5 & 8,3 & 8,2 \\
\hline Moldova & 13,8 & 13,3 & 13,2 & 13,0 & 12,9 \\
\hline Slovakia & 6,3 & 6 & 5,9 & 5,7 & 5,6 \\
\hline Spain & 3,7 & 3,6 & 3,5 & 3,3 & 3,3 \\
\hline Sweden & 2,4 & 2,4 & 2,3 & 2,1 & 2,1 \\
\hline Switzerland & 3,7 & 3,6 & 3,4 & 3,2 & 3,2 \\
\hline England & 4 & 3,9 & 3,8 & 3,6 & 3,5 \\
\hline Luxembourg & 1,7 & 1,6 & 1,55 & 1,5 & 1,4 \\
\hline Iceland & 1,7 & 1,6 & 1,6 & 1,5 & 1,4 \\
\hline Ukraine & 8,4 & 8,1 & 7,8 & 8,1 & 7,4 \\
\hline EU & 4 & 3,9 & 3,85 & 3,8 & 3,78 \\
\hline
\end{tabular}

Table. II. Dynamics of perinatal mortality in the EU and the world for the period 2012-2016 (per 1000 births alive and dead).

\begin{tabular}{|c|c|c|c|c|c|}
\hline Year & 2012 & 2013 & 2014 & 2015 & 2016 \\
\hline Austria & 2.96 & 3.13 & 2.88 & 2.9 & 2.85 \\
\hline Belorussia & 2.94 & 2.95 & 2.83 & 2.92 & 2.93 \\
\hline Belgium & 4.24 & 3.78 & 4.03 & 4.12 & 4.09 \\
\hline Bulgaria & 10.95 & 10.29 & 10.41 & 9.09 & 9.2 \\
\hline Czech Republic & 3.63 & 2.93 & 3.1 & 2.95 & 3.23 \\
\hline France & 11.58 & 11.71 & 11.78 & 11.81 & 11.79 \\
\hline Georgia & 11.63 & 10.89 & 9.1 & 9.24 & 9.05 \\
\hline Germany & 5.29 & 5.45 & 5.45 & 5.59 & 5.42 \\
\hline Hungary & 4.03 & 3.85 & 4.23 & 4.14 & 3.94 \\
\hline Iceland & 2.23 & 1.17 & 2.78 & 2.62 & 2.51 \\
\hline Luxembourg & 4.66 & 3.98 & 2.88 & 4.53 & 4.24 \\
\hline Holland & 3.66 & 3.76 & 3.69 & 3.55 & 3.42 \\
\hline Poland & 4.14 & 3.74 & 3.45 & 4.96 & 4.51 \\
\hline Portugal & 3.35 & 4.16 & 5.14 & 4.43 & 4.21 \\
\hline Moldova & 8.35 & 8.19 & 8.24 & 7.65 & 7.78 \\
\hline Romania & 6.22 & 6.49 & 6.62 & 6.04 & 6.24 \\
\hline Russia & 6.92 & 6.58 & 6.24 & 5.77 & 5.51 \\
\hline Slovakia & 4.7 & 4.16 & 4.58 & 4.79 & 4.42 \\
\hline Spain & 4.64 & 4.59 & 4.57 & 4.34 & 4.29 \\
\hline Sweden & 3.17 & 3.42 & 3.49 & 3.12 & 3.04 \\
\hline Switzerland & 2.79 & 3.02 & 2.89 & 2.79 & 2.58 \\
\hline Ukraine & 9.78 & 9.1 & 9.26 & 9.1 & 8.59 \\
\hline EU & 6.09 & 6.09 & 5.97 & 6.04 & 6.01 \\
\hline
\end{tabular}


Table. III. Dynamics of perinatal mortality in children with low and normal weight ( $\geq 1000 \mathrm{~g}$ ) in Ukraine and the EU and the world for the period $2012-2016$

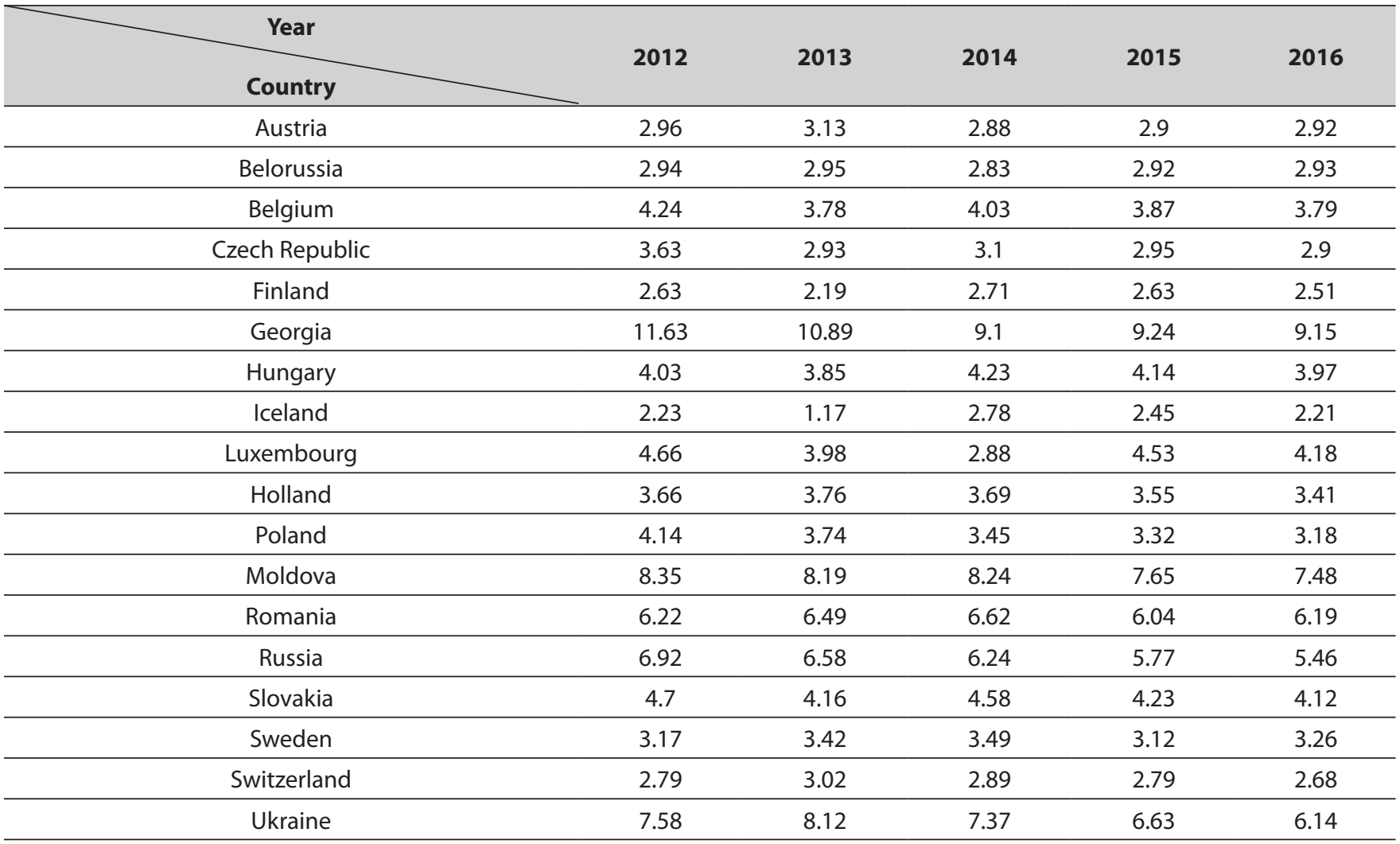

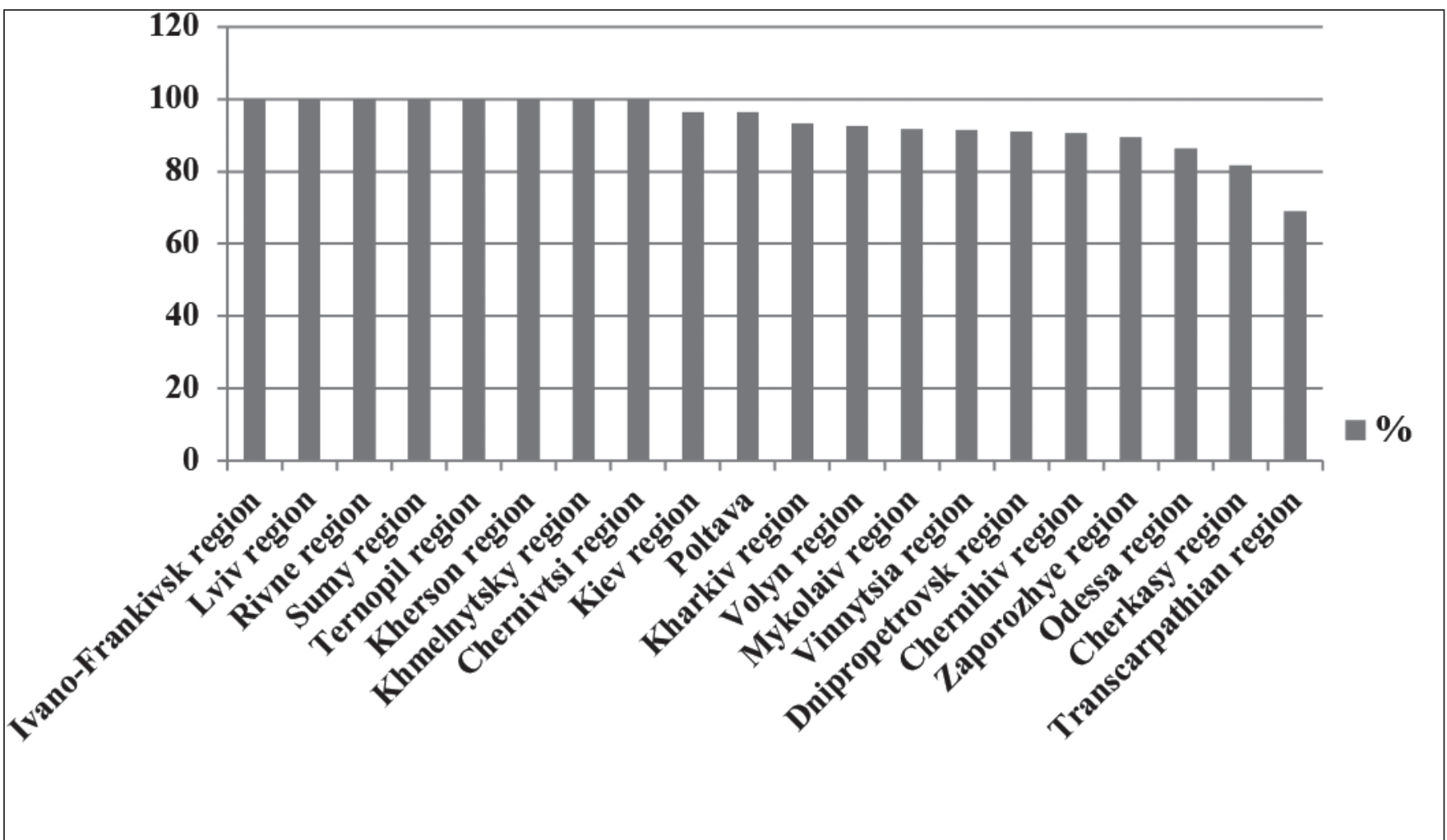

Figure. 2. The survival rate of newborns with low body weight (1000-1499 g) in the Transcarpathian region and other regions of Ukraine in 2014

As can be seen from the diagram, the Transcarpathian region in 2014 had a low survival rate for this cohort of newborns, and this despite the fact that, according to the Center for State Statistics of the Ministry of Health of Ukraine, Transcarpathia is one of the most positive demographic indicators, in particular the birth rate, among other regions and in comparison with the national average. 


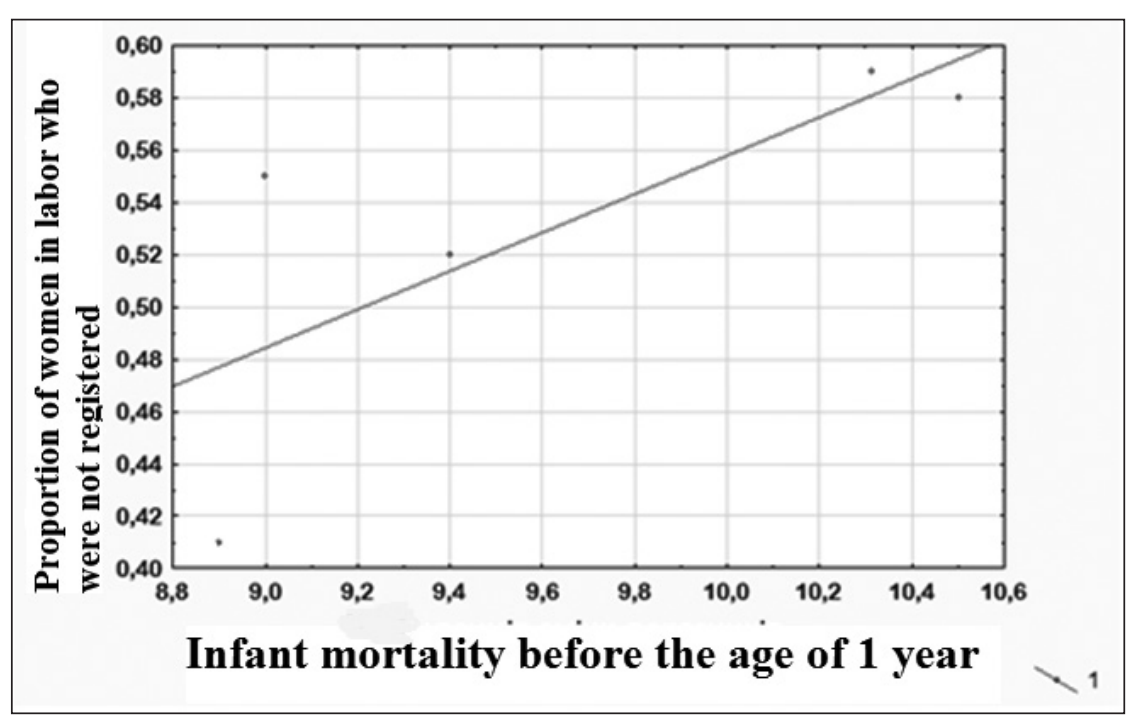

Figure. 3. Regression model of the dependence of infant mortality rates and the proportion of women who gave birth without ever attending a women's consultation (2016).
According to WHO, the main reasons for the high level of perinatal mortality and infant mortality in Ukraine, as in most European countries, are not only the deficiencies of the PC system, but also the attitude of future mothers to their health and the health of the unborn child. If in developed EU countries the indicator of the proportion of women who have given birth without ever having visited the antenatal clinic is practically zero, then in Ukraine this indicator ranges from $0.3-1 \%$. In the Transcarpathian region, in particular, this coefficient with a positive trend of changes for the period 2012-2016. Still holding high. When constructing a regression model between the mortality rates of infants and the proportion of women who gave birth in Transcarpathia, never having visited a antenatal clinic, we obtained reliable data on the dependence of these two indicators (Figure. 3 ).

Thus, the above fact confirms that the system of perinatal care in the region requires regionalization in order to save those lives that we can save with the adequate functioning of the internal and external sides of the RPC system.

Minimization of the weaknesses of the internal environment of the RPC should be aimed at completing the development of regional regulatory legal acts on the creation of a three-level system of perinatal care in the region and its implementation by creating a level III regional perinatal center in the Transcarpathian region; the creation of a level II regional perinatal center, viewing programs for pre- and postgraduate training of medical workers providing perinatal care of I-III levels; increasing the availability of highly specialized perinatal care in rural areas, including in mountainous and remote areas of all regions, for pregnant women with diabetes; development and implementation of a system of planning, medical observation, early intervention and palliative care for young children with chronic perinatal pathology $[7,8]$.

The prospect of further research is the study and analysis of the structure and rates of perinatal mortality in the Transcarpathian region and Ukraine in comparison with other EU countries and the world in order to verify "weaknesses" and deficiencies in the existing PC system.

\section{DISCUSSION}

The key to the successful implementation of the RPC system in any region with its subsequent effective functioning is not only the development of functional models, although without them in any way, but their adaptation to a specific situation with maximum fit and the solution of all related issues on the way of their implementation in practical activities. For the most adequate prediction of the efficiency of the RPC system, it is necessary to determine the weak link of the existing system. According to the latest WHO recommendations, indicators that can give the most objective information about the work of an individual PC link are: mortality of infants up to 1 year old and its structure, perinatal mortality and its structure, indicators of the morbidity of the child population with an analysis of the structure, and indicators of the state of health of the maternal population. The main ones listed are precisely mortality up to 1 year (infant mortality) and perinatal mortality.

This article highlights part of a dissertation research. The results of our study objectively revealed the urgency of the problem in the Transcarpathian region and in Ukraine as a whole compared with the countries of the European region and the world, the data are reliable and exhaustive. It is proved that at the primary and secondary levels of organization of perinatal care for the population, there are serious shortcomings, which ultimately lead to a deterioration in the health status of the child population. The possible causes of this problem described by us require scientific justification and evidence.

The prospect of this study is the study of the impact on the level of perinatal mortality and infant mortality problems in the staffing of this link in medical care. As you know, in the Transcarpathian region and Ukraine today there is a very active emigration of highly qualified personnel outside the country. There is also a problem with financial and logistical support, as well as with the quality of training of young specialists. The purpose of further research will be to identify a possible relationship between these factors and the development of a perfect model for 
the functioning of perinatal services in the region and in Ukraine as a whole.

\section{CONCLUSIONS}

1. The infant mortality rate (up to 1 year) in the Transcarpathian region is higher than the national average, and significantly higher than the average European.

2. The indicators of perinatal mortality, both general and in certain weight categories, born alive and dead, in our country are relatively high. Separately, this concerns the fact that children with low and normal body weight at birth still die too often in Ukraine, which is unacceptable from the point of view of $\mathrm{WHO}$ and developed EU countries, which minimized these losses decades ago.

3. In the study area, while maintaining relatively high birth rates and natural growth, the lowest survival rate for children with low body weight (1000-1499 g) is observed, which indicates significant shortcomings in the work of individual parts of the system of medical care for mother and child. These facts are confirmed by the relationship between the mortality rate of infants and the proportion of women who have given birth without having ever visited a antenatal clinic (or not registered).

\section{REFERENCES}

1. Dudina 0.0 , Tereshchenko A.V. Stan rehionalizatsii perynatalnoi dopomohy v Ukraini [The state of regionalization of perinatal care in Ukraine]. DU «Ukrainskyi instytut stratehichnykh doslidzhen MOZ Ukrainy», m. Kyiv, Ukraina, Ministerstvo okhorony zdorovia Ukrainy, m. Kyiv, Ukraina.-PERINATOLOGIYA I PEDIATRIYA. 2015;3(63):10-11. (InUkrainian).

2. Palii 0.M., Rynhach N.0. Rezervy znyzhennia smertnosti nemovliat v Ukraini [Reserves for reducing infant mortality in Ukraine]. Demohrafiia ta sotsialna ekonomika. 2011;2 (16):85-86. (InUkrainian).

3. Aksonova S. Yu. Osoblyvosti narodzhuvanosti u zhinok serednoho viku [Features of fertility in middle-aged women]. Demohrafiia ta sotsialna ekonomika. 2009;2(12):28-38. (InUkrainian).

4. Levchuk N. Smertnist nemovliat v Ukraini: iliuzii ta realnist [Infant mortality in Ukraine: illusions and reality]. Demohrafichni doslidzhennia : zb. nauk. prats. Kiyv: NAN Ukrainy, In-t ekonomiky. 2002;24:63-65. (InUkrainian).

5. Wagner M. Infant Mortality in Europe: Implication for the United States. Statement to the National Commission to Prevent Infant Mortality J. Of Public Health Policy. 1988;9(4):473-484.

6. Zakir M. Factors affecting infant mortality rates: evidence from crosssectional data. Applied Economics Letters. 1999;6:271-273.
7. Shchorichna dopovid pro stan zdorovia naselennia, sanitarnoepidemichnu sytuatsiiu ta rezultaty diialnosti systemy okhorony zdorovia Ukrainy. 2016 rik [The annual report on the state of public health, the sanitary-epidemic situation and the results of the health care system of Ukraine. 2016 year]. MOZ Ukrainy, DU «UISD MOZ Ukrainy». - Kyiv, 2017:101-109.(In Ukrainian).

8. Olena Nizalova, Nataliia Shapoval, Olga Nikolaieva. Current Population Health Needsand Their Regional Distributionin Ukraine. Centre for Health Services Studies, University of Kent Canterbury Kent. 2017:6-27.

This study (article) was carried out as part of the research work "The scientific rationale for monitoring the factors affecting the health of the population of the Transcarpathian region and the formation of modern management in the healthcare system.» State registration number: 3A-2015 No.0115U003907 dated 01/01/2016.

\section{ORCID and contributionship:}

Ivan M. Rogach - 0000-0001-6112-3934 ${ }^{\text {A, D, E, F }}$ Gennady O. Slabkiy - 0000-0003-2308-7869 A, B, E, F Renata Y. Pogorilyak - 0000-0002-7388-9969 C, D, E Angelika O. Keretsman - 0000-0002-8902-2227 C, E, F Ivan I.Gadzhega - 0000-0002-8638-6762 ${ }^{\text {B, C, D, F }}$

\section{Conflict of interest:}

The Authors declare no conflict of interest.

\section{CORRESPONDING AUTHOR}

\section{Ivan I. Gadzhega}

Uzhhorod National University,

Sq. Narodna 3, 88000 Uzhhorod, Ukraine

tel: +38 (095) 168-29-98;

e-mail: ivan.gadzhega@uzhnu.edu.ua;

kaf-socmed@uzhnu.edu.ua

Received: 17.01 .2020

Accepted: 05.03.2020

A - Work concept and design, B - Data collection and analysis, C - Responsibility for statistical analysis, D-Writing the article, $\mathbf{E}$ - Critical review, $\mathbf{F}$ - Final approval of the article 